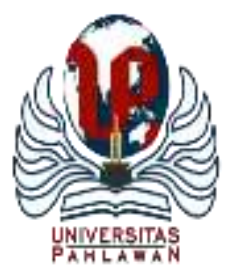

\title{
JURNALBASICEDU
}

Volume 5 Nomor 6 Tahun 2021 Halaman 5961 - 5967

Research \&Learningin Elementary Education

https://jbasic.org/index.php/basicedu

\section{Aktualisasi Nilai - Nilai Pancasila Melalui Mata kuliah Pendidikan Pancasila}

\author{
Muhammad Awin Alaby \\ Program Studi Pendidikan Anak Usia Dini, Sekolah Tinggi Keguruan Ilmu Pendidikan Kusumanegara \\ Jakarta, Indonesia \\ E-mail: alaby@ @tkipkusumanegara.ac.id
}

\begin{abstract}
Abstrak
Penelitian ini bertujuan untuk mengetahui seberapa besar pengaruh pemahaman mahasiswa PG Paud STKIP Kusumanegara tentang nilai-nilai Pancasila yang telah diajarkan melalui mata kuliah pendidikan Pancasila. Perlu diketahui bahwa pendidikan merupakan suatu usaha sadar dan terencana untuk mengembangkan dan membentuk karakter serta peradaban bangsa yang bermartabat dalam rangka mencerdaskan kehidupan bangsa, bertujuan untuk berkembangnya potensi peserta didik agar menjadi manusia yang beriman, bertakwa kepada Tuhan YME, berakhlak mulia, sehat, berilmu, cakap, kreatif, mandiri dan menjadi warga negara yang demokratis sehingga potensi yang dimiliki setiap individu dapat direalisasikan. Metode dalam penelitian ini menggunakan metode kualitatif deskriptif dengan contoh kasus. Contoh kasus digunakan untuk memberikan pemahaman pada sesuatu yang menarik perhatian dan mampu memahami kompleksitas satu kasus. Metode penelitian menggunakan metode kualitatif dengan melakukan pengumpulan data secara online melalui sevima edlink. Hasil penelitian ini menemukan seberapa besar keterpahaman mahasiswa PG Paud STKIP Kusumanegara yang sudah bisa mengaktualisasikan nilai-nilai Pancasila yang telah diajarkan melalui mata kuliah pendidikan Pancasila. Aktualisasi nilai - nilai Pancasila berupa melaksanakan kewajiban sesuai ajaran agama yang dianut, hidup toleransi, peduli sosial, sopan, dan santun. Penelitian ini berupaya agar nilai-nilai pancasila bisa terus diwariskan kepada generasi bangsa untuk bisa menjadi bangsa yang kuat dan berkarakter.
\end{abstract}

Kata Kunci : Aktualisasi, Nilai-nilai Pancasila, Pendidikan Pancasila

\begin{abstract}
This study aims to determine how much influence the understanding of PG Paud STKIP Kusumanegara students about Pancasila values that have been taught through Pancasila education courses. It should be noted that education is a conscious and planned effort to develop and shape the character and civilization of a dignified nation in the context of educating the nation's life, aiming at developing the potential of students to become human beings who believe, fear God Almighty, have noble character, are healthy, knowledgeable, capable, creative, independent and become a democratic citizen so that the potential of each individual can be realized. The method in this study uses descriptive qualitative methods with case examples. Case examples are used to provide insight into something that is of interest and is able to understand the complexity of a single case. The research method uses qualitative methods by collecting data online through Sevima Edlink. The results of this study found how much understanding the students of PG Paud STKIP Kusumanegara had who were able to actualize the values of Pancasila that had been taught through Pancasila education courses. The actualization of Pancasila values is in the form of carrying out obligations according to the teachings of the religion adhered to, living a life of tolerance, social care, courtesy, and courtesy. This research seeks to make the values of Pancasila continue to be passed on to the younger generation to become a strong and characterized nation.
\end{abstract}

Key words: Actualization, Pancasila Values, Pancasila Education

Copyright (c) 2021 Muhammad Awin Alaby

$\triangle$ Corresponding author :

Email : alaby@stkipkusumanegara.ac.id

DOI : https://doi.org/10.31004/basicedu.v5i6.1750

ISSN 2580-3735 (Media Cetak)

ISSN 2580-1147 (Media Online) 
DOI: https://doi.org/10.31004/basicedu.v5i6.1750

\section{PENDAHULUAN}

Indonesia mempunyai etika nasional yang dirumuskan dalam pancasila. Pancasila merupakan Falsafah hidup, dasar negara, dan pemersatu bangsa Indonesia yang plural. sebab karena itu Pancasila disebut sebagai kepribadian bangsa Indonesia, sebagai falsafah, ideologi, dan alat pemersatu bangsa Indonesia. (Alaby, 2020).

Semua rakyat Indonesia tentunya sudah mengenal dasar negara Indonesia. Karena sebagai rakyat tidak mungkin tidak mengetahui dasar negaranya sendiri. Pancasila yang dilambangkan dengan burung garuda berisikan lambang-lambang yang menggambarkan acuan dari dasar negara. Dasar negara atau disebut sebagai pondasi negara ini. Pancasila dijadikan landasan utama negara Indonesia yang dijadikan pedoman untuk penyelenggaraan hidup bernegara. (Lestari, Slamet, \& Noorochmat, 2017).

Sehari setelah Indonesia merdeka Pancasila dinyatakan sah sebagai dasar negara. Pancasila sudah melalui proses yang cukup panjang ketika perumusan, karena itu akan menjadi dasar negara Indonesia maka tidak mungkin hanya asal-asalan sehingga akhirnya terbentuklah ideologi Pancasila yang saat ini kita jadikan pandangan hidup (Abdulgani, 1998). Pancasila dibuat untuk mengatur kehidupan bangsa dan negara Indonesia dari sejak disahkan hingga saat ini. Pancasila tidak dapat diubah, jika diubah saja tidak diperbolehkan maka menghilangkannya sangat tidak boleh, karena mengubah pancasila itu sama saja seperti membubarkan negara ini yang sudah utuh dan final yang telah diperjuangkan oleh para Founding Fathers kita (A.Hamid S, 1991).

Sebagai warga negara Indonesia sudah selayaknya mengamalkan nilai - nilai Pancasila yang salah satunya yaitu selalu menjunjung tinggi ideologi Pancasila dalam sila kedua yang berisi kemanusiaan yang adil dan beradab. Dengan menjujung tinggi kemanusiaan yang adil dan beradab, maka manusia sama sekali tidak akan dirugikan oleh siapapun atau apapun juga karena hal tersebut termasuk perilaku terpuji. Sila kedua Pancasila tersebut menjelaskan bahwa setiap warga negara Indonesia harus berprikemanusiaan, yang berarti setiap keputusan dan tindakan yang menyangkut kemanusiaan mensyaratkan adanya kesetaraan manusia.

Kesetaraan dalam sila kedua Pancasila mengeksplisitkan kemungkinan-kemungkinan adanya penerimaan pada perbedaan. Makna yang dimaksud secara garis besar artinya berbeda-beda tetapi tetap satu jua yang bila dilihat secara teperinci bahwa di negara ini banyak sekali pulau yang berisi berbagai macam suku, ras, ataupun budaya yang dipersatukan oleh negara Indonesia. Warga negara Indonesia juga tidak hanya menganut satu agama saja, namun berbagai macam agama dan kepercayaan yang diakui masyarakat sangatlah beragam. Jadi tidak semua orang dalam negeri ini harus menganut agama dan kepercayaan yang sama (Wanti, 2017).

Keberagaman itu bukanlah suatu perbedaan yang menjadikan permusuhan antar suatu kaum, namun setiap orang saling bertoleransi antar suku, agama, ras, budaya dan kepercayaan. Meskipun memiliki perbedaan, negara Indonesia tetap bersatu berdaulat adil dan makmur karena Indonesia itu negara kesatuan, yang memiliki pemikiran satu nusa, satu bangsa, dan menjunjung satu bahasa persatuan, Indonesia guna mencapai suatu kemerdekaan yang tenang dalam suatu negara. Bangsa Indonesia harus satu jiwa dan satu pandangan hidup. Situasi atau perbedaan tidak menghalangi persatuan bangsa Indonesia, setiap orang memiliki toleransi, kegotong royongan, nilai saling menghargai dan menghormati, sehingga tercipta persatuan dan kesatuan (Alaby, 2020).

Pancasila dengan nilai kemanusiaan yang adil dan beradab menandai karakter khas dalam diri warga negara Indonesia yang terlahir melalui proses sejarah yang cukup panjang, sejak zaman neolitikum hingga sampai datangnya bangsa asing yang menguasai bangsa Indonesia ini. Untuk itu, dalam konteks hidup bersama, kesetaraan hak dari setiap warga negara menjadi hal penting yang diupayakan. Hal kesetaraan dalam kehidupan yangsaat ini masih ada yang menyimpang, padahal setiap warga negara Indonesia memiliki hak yang setara dalam pemenuhan kesejahteraan. Selain itu, juga kesetaraan dalam kehidupan yang layak, hak politik, hukum, dan semua hal yang telah diatur diundang- undang tanpa melihat suku dan ras warga negara Indonesia tersebut. 
DOI: https://doi.org/10.31004/basicedu.v5i6.1750

Aktualisasi nila-nilai pancasila menjadi hal yang sangat mendesak mengingat hasil pendidikan tidak berbading lurus,.(Kartono, 1977) hal ini dapat dibuktikan dengan masih adanya demoralisasi moral dan degradasi pengetahuan yang sudah menjadi akut menjangkit bangsa ini di semua strata masyarakat. Degradasi moral yang diderita jika tidak ditangani secara khusus dan cepat akan membawa akibat yang berdampak sangat buruk bagi generasi mendatang.(Azahra Dewanti Galuh, Delia Maharani, Latifah Meynawati, Dinie Anggraeni, 2021).

\section{METODE PENELITIAN}

Penelitian ini menggunakan metode kualitatif deskriptif. Metode ini digunakan peneliti agar masalah yang diangkat oleh peneliti dapat teruraikan lebih dalam dan menjadi acuan teori bagi peneliti lain dalam menganalisis data yang bersifat tidak langsung.(Moleong, 2007) Analisis data yang digunakan oleh peneliti ini dilaksanakan sebelum observasi dilakukan dilapangan. Analisis yang digunakan oleh peneliti adalah analisis domain yang peneliti hasilkan dari suatu konsep dasar umum atas objek yang diteliti atau teknik bagaimana situasi sosial itu dapat menghasilkan sesuatu. Sehingga masalah yang terjadi dari awal hingga akhir tidak terlalu banyak mengalami perubahan. Teknik penelitian ini didasari dengan kajian literatur kepada berbagai sumber agar lebih mendalami dan memahami suatu kajian yang akan diteliti oleh peneliti. (Sugiyono, 2018).

\section{HASIL DAN PEMBAHASAN}

Aktualisasi nilai pancasila perlu disosialisasikan, diinternalisasikan dan diperkuat penerapannya, dalam praktik kehidupan berbangsa dan bernegara dengan memperkuat karakter generasi bangsa dalam berperan serta membangun pemahaman masyarakat akan kesadaran nasional (Moerdiono, n.d.).

Aktualisasi nilai dalam praktek kehidupan berbangsa dan bernegara mengarahkan adanya 3 nilai yang terkandung dalam ideologi Pancasila,Tiga nilai itu adalah:

1. Nilai dasar, yaitu suatu nilai yang bersifat sangat abstrak dan permanen, yang terlepas dari pengaruh perubahan waktu. Nilai dasar merupakan prinsip, yang bersifat sangat abstrak, bersifat sangat umum, tidak terikat oleh waktu dan tempat, dengan kandungan kebenaran yang bagaikan aksioma. Dari aspek kandungan nilainya, maka nilai dasar berkenaan dengan eksistensi sesuatu, yang mencakup cita-cita, tujuan, tatanan dasar dan ciri khasnya. Nilai dasar Pancasila ditetapkan oleh para the founding fathers. Nilai dasar Pancasila tumbuh baik dari sejarah perjuangan bangsa Indonesia melawan penjajahan yang telah menyengsarakan rakyat, maupun dari cita-cita yang ditanamkan dalam agama dan tradisi tentang suatu masyarakat yang adil dan makmur berdasarkan kebersamaan, persatuan dan kesatuan seluruh warga masyarakat. (Latif, 2011)

2. Nilai instrumental, yaitu suatu nilai yang bersifat kontekstual. Nilai instrumental merupakan penjabaran dari nilai dasar tersebut yang merupakan arahan kinerjanya. Negara memiliki peran dan tanggung jawab dalam pemenuhan hak yang setara dalam kesejahteraan bagi seluruh rakyat Indonesia, negara tidak boleh membeda bedakan suku, ras, budaya, agama atau hal-hal lain karena seperti misalnya ketika pemerintah akan memberi hukuman kepada orang yang salah namun salah satunya memiliki latar belakang yang tinggi dan orang yang benar memiliki latar belakang atau status ekonomi yang kurang lalu pemerintah memberi hukuman kepada orang yang salah dengan strata sosial tinggi maka pemerintah sudah bertindak tidak adil terhadap masyarakatnya (Ariawantara, 2016). Manusia pasti akan meninggalkan kehidupan di bumi ini. Berbagai macam alasan dibuat demi membenarkan perilaku yang salah dalam kehidupan ini, mulai dari politik, ekonomi, dendam pribadi, sampai atas nama agama bahkan Tuhan.untuk kurun waktu tertentu dan untuk kondisi tertentu. Nilai instrumental ini dapat dan bahkan harus disesuaikan dengan tuntutan zaman. Namun nilai instrumental haruslah mengacu pada nilai dasar yang dijabarkannya.(Kaelan, 2014) Penjabaran 
itu bisa dilakukan secara kreatif dan dinamik dalam bentuk-bentuk baru untuk mewujudkan semangat yang sama, dalam batas-batas yang dimungkinkan oleh nilai dasar itu. Dari aspek kandungan nilainya, maka nilai instrumental merupakan kebijaksanaan, strategi, organisasi, sistem, rencana, program, bahkan juga proyekproyek yang menindak lanjuti nilai dasar tersebut. Lembaga negara yang berwenang menyusun nilai instrumental ini adalah DPR, MPR, dan Presiden.

3. Nilai praksis, yaitu nilai yang terkandung dalam kenyataan sehari-hari, berupa cara bagaimana rakyat mengaktualisasikan nilai Pancasila. Nilai praksis terdapat pada demikian banyak wujud penerapan nilai-nilai Pancasila, baik secara tertulis maupun tidak tertulis, baik oleh cabang eksekutif, legislatif, maupun yudikatif, oleh ekonomi, oleh pimpinan kemasyarakatan, bahkan oleh warga negara secara perseorangan. Dari aspek kandungan nilainya, nilai praksis merupakan arena pergulatan antara idealisme dan realitas. Jika ditinjau dari segi pelaksanaan nilai yang dianut, maka sesungguhnya pada nilai praksislah ditentukan tegak atau tidaknya nilai dasar dan nilai instrumental itu. Singkatnya bukan pada rumusan abstrak, dan bukan juga pada kebijaksanaan, strategi, rencana, program atau proyek itu sendiri terletak batu ujian terakhir dari nilai yang dianut, tetapi pada kualitas pelaksanaannya di lapangan (Kaelan, 2013).

Bagi suatu ideologi, yang paling penting adalah bukti pengamalannya atau aktualisasinya dalam kehidupan bermasyarakat, berbangsa, dan bernegara. Suatu ideologi dapat mempunyai rumusan yang amat ideal dengan ulasan yang amat logis serta konsisten pada tahap nilai dasar dan nilai instrumentalnya. Akan tetapi, jika pada nilai praksisnya rumusan tersebut tidak dapat diaktualisasikan, maka ideologi tersebut akan kehilangan kredibilitasnya. Ancaman terbesar bagi suatu ideologi adalah menjaga konsistensi antara nilai dasar, nilai instrumental, dan nilai praksisnya. Sudah barang tentu jika konsistensi ketiga nilai itu dapat ditegakkan, maka terhadap ideologi itu tidak akan ada masalah. Jika terdapat inkonsisitensi dalam tiga tataran nilai tersebut maka akan menjadi suatu masalah baru (Widjaja, 2004).

Menerapkan nilai-nilai Pancasila di masyarakat tentu dimulai dari sekitar lingkungan rumah. Keberagaman etnis yang ada di masyarakat hendaknya menjadi suatu warna tersendiri bagi mereka, sebagaimana semboyan yang dimiliki bangsa Indonesia yaitu “Bhinneka Tunggal Ika, walaupun negara Indonesia terdiri dari beragam suku, namun kerukunan antar seluruh umat di Indonesia tetap perlu dijunjung tinggi (Suparlan, 2014). Dengan cara kembali melakukan aktualisasi nilai - nilai pancasila di berbagai aspek moral bangsa Indonesia sehingga dapat kembali menuju jati dirinya, nilai pancasila tersebut akan terimplementasi dalam ranah kognitif, afektif dan psikomotorik bangsa. Hal demikian sangat penting untuk diingat karena dapat menjadi parameter atau tolak ukur sampai seberapa jauh tingkat perubahan tingkah laku seseorang, dan untuk mengetahui tingkat ketercapaian dalam menempuh proses pendidikan (Alaby, 2019).

Pancasila dibuat bermaksud untuk kebaikan bagi manusia dan diciptakan melalui suatu kesepakatan supaya terciptanya karakter yang positif (Lala, 2019). Manusia sudah mengalami perang dunia kedua secara tidak langsung ketika manusia seolah-olah berusaha dan bersaing untuk membunuh sesama manusia dalam jumlah jutaan. Tidak ada yang menyadarinya karena kebenaran selalu tertutup oleh berbagai alasan yang tercipta (Janah, Hanif, 2015). Hal tersebut tidak bisa dibiarkan begitu saja, karena kemanusiaan yang adil dan beradab sesuai dengan sila kedua dari Pancasila tidak teraktualisasikan adanya. Hal tersebut sangat menyimpang, kebenaran ditutupi dan yang benarkan sangat dirugikan baik saat kejadian maupun masa depannya (Lestari et al., 2017).

Kemanusiaan yang adil dan beradab dalam sila kedua juga bermakna bahwa bangsa Indonesia diakui dan diperlakukan sesuai harkat dan martabat sebagai makhluk ciptaan Tuhan Yang Maha Esa. Sebagai makhluk ciptaan Tuhan Yang Maha Esa, manusia memiliki derajat, hak, dan kewajiban yang sama. Setiap insan tidak dibeda-bedakan berdasarkan latar belakangnya seperti suku, agama, ras, budaya, status, dan keturunan (Gultom, 2016). Selain itu, bangsa Indonesia juga menjunjung tinggi hak asasi manusia (HAM) 
Dimata hukum yang berlaku,setiap orang juga diperlakukan secara adil,yakni sama dan setara. Poin penting dalam penelitian ini menandakan bahwa kesetaraan hak warga negara didasarkan pada adanya perlakuan adil dan setara. Artinya, dalam kesetaraan hampir selalu memuat dimensi keadilan.

Hal ini didasarkan pada kenyataan bahwa hal yang mendasar yang harus diterima bahwa warga indonesia dengan latar belakang apapun perlu mendapatkan perlindungan, walaupun ada perbedaan di antara warga negara. Namun, saat ini lebih berdampak kebalikannya. Secara tidak adil, tidak sama dan tidak setara. Contohnya banyak sekali ditambah dengan mudahnya informasi yang menyebar ketika teknologi ini sudah canggih membuat orang-orang mengikuti yang namanya tren, tanpa mengetahui maksud dari tren tersebut. Seperti hal yang baru saja terjadi, pola pikir masyarakat mulai Berubah ketika saat ada orang melakukan kesalahan namun tetap dibela dengan alasan karena good looking, menyebarnya kata tersebut membuat semua orang berpemikiran sedemikian rupa. Memandang manusia sebelah mata, hanya dilihat dari rupa, bukan dilihat dari keberadaban orang tersebut. Orang yang good looking akan memenangkan segala hal (Ridlwan, 2014).

Tentunya hal itu sangat tidak dibenarkan, kita sebagai manusia tidak boleh membeda-bedakan antara manusia yang satu dangan manusia lainnya. Kemanusiaan yang adil dan beradab akan mulai memudar, tergantikan dengan kericuhan. Jika satu sila dari Pancasila rumpang maka pancasila tidak akan berdiri, karena pada hakikatnya Pancasila itu harus ada lima tidak boleh berkurang atau bertambah. Sebab sila-sila Pancasila memiliki susunan hierarkhis piramidal yang mana sila pertama menjadi basis dari sila ke dua sampai ke lima (Notonagoro, 1967). Sebaliknya Ketuhanan Yang Maha Esa adalah Ketuhanan yang berkemanusiaan, berpersatuan, berkerakyatan serta berkeadilan sosial sehingga di dalam setiap sila senantiasa terkandung silasila lainnya. Sila pertama meliputi dan menjamin sila 2,3,4,dan 5. Sila kedua diliputi dan dijiwai oleh sila 1 , meliputi dan menjiwai sila 3, 4,dan 5. Sila ketiga diliputi dan dijiwai sila 1,2. meliputi dan menjiwai sila 4,dan 5. Sila keempat diliputi dan dijiwai oleh sila 1,2,3, meliputi dan menjiwai sila dan 5. Sila kelima diliputi dan dijiwai sila 1,2,3,dan 4 (Kaelan, 2010).

Keadaan masa depan jika dilihat saat ini saja masyarakat sudah lupa akan nilai-nilai Pancasila yang terkandung. Bukankah mudah jika sesama manusia saling menghormati, menghargai dan adil kepada semua orang. Contoh sikap yang memenuhi hak yang setara dalam kesejahteraan bagi seluruh rakyat indonesia yaitu melakukan donor darah, karena tindakan pengambilan darah dengan volume tertentu melalui pembuluh darah. Darah kemudian diproses oleh PMI untuk kemudian digunakan sebagai pengganti darah kepada orang yang membutuhkan. Termasuk kegiatan sosial yang adil dan beradab.

Tuhan Yang Maha Esa memberi darah yang cukup kepada manusia ,dan manusia lain yang membutuhkan darah terpenuhi kebutuhannya dengan pemberian darah dari orang lain. Hal tersebut saling menguntungkan karena selain penerima donor mendapatkan darah, pendonor juga mendapat banyak manfaat. Sikap lain yang mencerminkan sila kedua pancasila dalam kehidupan sehari-hari diantaranya menghormati hak orang lain, bertindak adil tanpa memandang ras, ruku, agama, dan status sosial, menghargai pendapat, berani mengakui kesalahan, mengunjungi teman yang sakit, memberi santunan kepada orang miskin, berani membela orang yang tidak bersalah, memberi tempat duduk pada wanita hamil diangkutan umum, tidak membedakan derajat manusia, membantu korban bencana alam. Dengan pemenuhan kesetaraan hak warga negara yang mengalami kekurangan, ketertindasan, kemiskinan, maka keadilan perlu diwujudkan supaya terwujud manusia yang beradab. Dengan nilai yang beradab, warga negara bisa bersama-sama hidup dalam kedamaian dan kesejahteraan.

Keanekaragaman masyarakat Indonesia selain dapat menjadi kebanggaan namun dapat juga menjadi suatu bentuk ancaman serius bagi bangsa Indonesia. Adanya keanekaragaman memungkinkan suatu komunitas masyarakat dapat memilih untuk hidup berkelompok dengan orang lain yang mungkin saja berbeda dengan ras, suku, budaya atau bahasa yang dimiliki. Namun adanya keberagaman ini kondusifitas berpotensi 
DOI: https://doi.org/10.31004/basicedu.v5i6.1750

terjadi sehingga menjadikan kelompok - kelompok tersebut saling membenci berdasarkan perbedaan yang ada di antara mereka (Suparlan, 2014).

Menghadapi tantangan kedepan, bangsa Indonesia harus waspada dan siap dalam menghadapi era globalisasi seperti di bidang ekonomi, kemudian ancaman bahaya laten terorisme, komunisme dan fundamentalisme. Hal-hal tersebut menjadi suatu tantangan tersendiri bagi bangsa Indonesia, yang bila mana kita sebagai suatu bangsa tidak bisa bersatu alias dalam kondisi terpecah belah, maka besar kemungkinan bangsa kita akan gagal dalam menghadapi tantangan-tantangan tersebut. Sebuah negara harus berlandaskan demokrasi agar menjadi ideal (Sudrajat, 2016).

Sila kedua dibutuhkan guna menangkal berbagai macam ancaman kemanusiaan serta untuk menegakkan nilai - nilai universal kemanusiaan di negara ini. Selain itu sila ini juga harus mampu menjamin hukum yang adil bagi masyarakat secara keseluruhan, utamanya demi penegakan HAM yang bermartabat. Nilai yang terkandung dalam sila kedua bila diaktualisasikan akan menjunjung tinggi martabat seorang manusia sebagai mahkluk sosial (Alaby, 2019).

\section{KESIMPULAN}

Dengan demikian dapat disimpulkan bahwa kesetaraan hak warga negara dalam pemaknaan sila kemanusiaan yang adil dan beradab yaitu pertama, kesetaraan hak warga negara didasarkan pada adanya perlakuan adil. Hal ini didasarkan pada kenyataan bahwa hal yang mendasar yang harus diterima bahwa warga negara Indonesia dengan latar belakang apapun perlu mendapatkan perlindungan, walaupun ada perbedaan di antara warga negara. Kemudian yang kedua, dengan pemenuhan kesetaraan hak warga negara, maka terwujud manusia yang beradab. Dengan nilai yang beradab, warga negara bisa bersama-sama hidup berdampingan dalam kedamaian. Adanya bentuk-bentuk konkret dalam ruang-ruang pembelajaran diperuntukkan agar nilai keadilan dan nilai yang beradab bisa diajarkan terus-menerus dan menjadi kebiasaan sehingga kesetaraan antar warga negara terwujud harmonis.

\section{DAFTAR PUSTAKA}

A.Hamid S. (1991). Pancasila Sebagai Ideologi Dalam Berbagai Bidang Kehidupan Bermasyarakat Dan Bernegara. Jakarta: Bp 7 Pusat.

Abdulgani, R. (1998). Pancasila Perjalanan Sebuah Ideologi. Jakarta: Lp3es.

Alaby, M. A. (2019). Membumikan Nilai Pancasila Pada Generasi Bangsa. Gema Wiralodra, 10(2). Https://Doi.Org/10.31943/Gemawiralodra.V10i2.75

Alaby, M. A. (2020). Menumbuhkan Kepribadian Bangsa Yang Berkarakter Pancasila. Jurnal Pendidikan Terintegrasi, $1(1)$.

Ariawantara, P. A. F. (2016). Implementasi Dalam Kehidupan Berbangsa Dan Bernegara. Unair.

Azahra Dewanti Galuh, Delia Maharani, Latifah Meynawati, Dinie Anggraeni, Y. F. F. (2021). Urgensi Nilai Dan Moral Dalam Upaya Meningkatkan Pendidikan Karakter Melalui Pembelajaran Pkn Di Sekolah Dasar. Jurnal Basicedu, Vol. $5 \quad$ N, 5169-5178. Https://Doi.Org/Doi: Https://Doi.Org/10.31004/Basicedu.V5i6.1598

Gultom, A. F. (2016). Enigma Kejahatan Dalam Sekam Filsafat Ketuhanan. Intizar, 22(1). Https://Doi.Org/10.19109/Intizar.V22i1.542

Janah, Hanif, N. (2015). Penanaman Nilai-Nilai Sila Kemanusiaan Yang Adil Dan Beradab Dalam Kegiatan Berorganisasi Disekolah. E-Prints.

Kaelan. (2010). Pendidikan Pancasila. Yogyakarta: Paradigma. 
5967 Aktualisasi Nilai - Nilai Pancasila Melalui Mata kuliah Pendidikan Pancasila - Muhammad Awin Alaby

DOI: https://doi.org/10.31004/basicedu.v5i6.1750

Kaelan. (2013). Negara Kebangsaaan Pancasila , Kultural, Historis, Filosofis, Yuridis Dan Aktualisasinya. Yogyakarta: Paradigma.

Kaelan. (2014). Pendidikan Pancasila. Yogyakarta: Paradigma.

Kartono, K. (1977). Holistik Mengenai Tujuan Pendidikan Nasional. Jakarta: Pradnya Paramita.

Lala, A. (2019). Implementasi Nilai Kemanusiaan Yang Adil Dan Beradab Dalam Pembangunan Hukum Pidana Nasional. Syntax Literate; Jurnal Ilmiah Indonesia, 4(5).

Latif, Y. (2011). Negara Paripurna:Historitas,Rasionalitas,Dan Aktualitas Pancasila. Jakarta: Gramedia Pustaka Utama.

Lestari, E. Y., Slamet, S., \& Noorochmat, I. (2017). Pemenuhan Hak Bagi Penyandang Disabilitas Di Kabupaten Semarang Melalui Implementasi Convention On The Rights Of Persons With Disabillities (Cprd) Dalam Bidang Pendidikan. Integralistik, 1 .

Moerdiono. (N.D.). Pancasila Dalam Ideologi Terbuka Menghadapi Era Globalisasi Dan Perdagangan Bebas. Majalah Mimbar, No.75 Tahun Xiii.

Moleong, L. J. (2007). Qualitative Research Methodology. Bandung: Pt.Remaja Rosdakarya.

Notonagoro. (1967). Beberapa Hal Mengenai Falsafah Pantjasila. Jakarta: Pantjuran Tujuh.

Ridlwan, Z. (2014). Negara Hukum Indonesia Kebalikan Nachtwachterstaat. Fiat Justisia:Jurnal Ilmu Hukum, 5(2). Https://Doi.Org/10.25041/Fiatjustisia.V5no2.56

Sudrajat, A. (2016). Demokrasi Pancasila Dalam Perspektif Sejarah. Mozaik: Jurnal Ilmu-Ilmu Sosial Dan Humaniora, 8(1). Https://Doi.Org/10.21831/Moz.V8i1.10763

Sugiyono. (2018). Metode Penelitian Pendidikan (Pendekatan Kualitatif,Kuantitatif, Dan R\& D) (Bandung). Alfabeta.

Suparlan, P. (2014). Bhinneka Tunggal Ika: Keanekaragaman Suku Bangsa Atau Kebudayaan?. Antropologi Indonesia.

Wanti, D. D. (2017). Proses Perumusan Pancasila Sebagai Dasar Negara Ri. Jurnal Ilmiah Mahasiswa Universitas Negeri Semarang.

Widjaja. (2004). Penerapan Nilai-Nilai Pancasila Dan Ham Di Indonesia. Jakarta: Rineka Cipta. 